\title{
Assessment of Some Commercial Fruit Juices Commonly Consumed In Federal University Of Technology-Owerri (FUTO) By Microbiological Indices
}

\author{
${ }^{1}$ Maduka,H.C.C., ${ }^{1}$ Onuorah,O.R., ${ }^{2}$ Okpogba A.N. ${ }^{2}$ Ugwu C.E,${ }^{2}$ Ogueche P.N., \\ $*^{2}$ Dike C.C., ${ }^{3}$ Maduka,A.A. \\ ${ }^{I}$ Department of Biochemistry, Federal University of Technology, Owerri, Nigeria. \\ ${ }^{* 2}$ Department of Human Biochemistry, College of Health Sciences Nnamdi Azikiwe University, P.M.B. 5001, \\ Nnewi-Anambra State, Nigeria. \\ ${ }^{3}$ Department of Gender Studies, The University of Hull, HU6 7RX, UK.
}

\begin{abstract}
A lot of beverages (fruit juices) are packaged and supplied commercially in owerri metropolis and consumed in Federal University of Technology, Owerri (FUTO). Some of these commercial fruit juices consumed in FUTO were assessed by microbiological indices. This was done by subjecting five group of fruit juices samples labeled $R_{I}-R_{5}$ to microbiological screening of the common bacteria contaminants of foods and beverages..The microbial parameters used as indices for analysis were bacteria counts and most probable number (MPN).The bacteria that were screened for include:Escherichia coli ( E.coli),Klebsiella pneumonia(K. pneumonia), Staphylococcus areus(S. areus),Salmonella typhimurium(S. typhmurium) and Streptococcus faecalis(S. faecalis).The MPN were: 1,3,2,2, for $R_{1}, R_{2}, R_{4}$, and $R_{5}$.There were no MPN for $R_{3}$. The \% bacteria count were $34.15 \%, 14.63 \%, 34.15 \%, 17.07 \%$, for E. coli, K. pneumoniae, S. aureus, and S. faecalis respectively. There was no bacteria count for S.typhmurium. Since none of the above mentioned species was detected in $R_{3}$ sample, it is safe for human consumption. The presence of the bacteria species in the other samples shows that the samples were contaminated even though the colonies of bacteria detected were not significant to cause infection.
\end{abstract}

Key words: Bacteria counts, Fruit juice, and Microbial screening .

\section{Introduction}

Juice can be defined as any natural fluid that can be extracted from a plant tissue or animal tissue by squeezing or cooking (1). Juices are often consumed for their perceived health benefits (2).For examples, orange juice which is rich in vitamin $\mathrm{C}$, folic acid and potassium is an excellent source of bioavailable antioxidant phytochemicals $(3,4)$ and significantly improves blood lipid profiles in people affected with hypercholesterolemia(1,5).Prune juice is associated with a digestive health benefit $(6)$.Cranberry juice has long been known to help prevent or even treat bladder infections(7) and it is now known that a substance in cranberries prevents bacteria from binding to the bladder(8).

Many fruit juices have higher sugar(fructose) content than sweetened soft drinks . Typical grape juice has 50\% more sugar than coca cola(9), while soft drinks cause oxidative stress when ingested and may even lead to insulin resistance in the long term ( 10).The same thing cannot be attributed to fruit juices(11).On the contrary, fruit juices are actually known for their ability to raise serum antioxidant capacity and even offset the antioxidant stress and inflammation normally caused by high fat and high-sugar meals(12).In a controlled clinical study, regular consumption of grape juice for 12 weeks did not cause any weight gain in volunteers, but consumption of soft drinks did(11).Fruit juice in moderate amount can help children and adults meet daily recommendations for fruit consumption ,nutrient intake and calories(13).In developing nations like Nigeria, it has not been possible to have control over the processing of hawked fruit juice, because most of the vendors lack the adequate knowledge of food processing and handling technique( 14). Various commercial fruit juices are sold in Federal University of Technology, Owerri (FUTO) and also consumed by staff and students. The nature, source and state of hygiene of foods and drinks consumed in the university have health implications on the academic society. This study, therefore investigated the common commercial fruit juices sold and consumed in FUTO using microbiological analysis of common bacterial contaminants of foods and drinks as index of evaluation. 


\subsection{Sources of materials}

\section{Materials And Methods}

The commercial fruit juices used as samples $R_{1}, R_{2}, R_{3}, R_{4}$ and $R_{5}$, were bought from shops at the commercial area of FUTO and were dispensed into clearly labeled test bottles $R_{1}, R_{2}, R_{3}, R_{4}$ and $R_{5}$ and were immediately stored in a refrigerator in the Department of Biochemistry laboratory for analysis.

\subsection{Microbial Screening}

This was carried out by inoculating freshly prepared media with the fruit juice samples and incubated at $37{ }^{0} \mathrm{C}$ for $24 \mathrm{hrs}$ and checked for any microbiological growth.

\subsection{Spread plate method}

The colony count was done using the spread plate method of Chessbrough(15). This was done by inoculating $0.5 \mathrm{ml}$ of diluted bacteria suspension over the surface of dry solid medium using a sterile spreader. The plate was incubated upside down. The colonies that appear on the agar surface were counted, the number of bacteria per $\mathrm{ml}$ estimated and the percentage $(\%)$ bacteria count was determined from the number of bacteria estimated. The most probable number (MPN) was done using multiple tube method for faecal coliform. The measured volumes of neat and diluted water were added to a series of tubes containing a liquid indicator growth medium. A characteristics colour change in any tube indicates the presence of indicator bacteria in the sample. The most probable number (MPN) of indicator organisms in the sample depends on the number and distribution of positive and negative reactions.

\section{Results}

The results of the most probable number (MPN) and microbial screening of five different samples $\left(\mathrm{R}_{1^{-}}\right.$ $\mathrm{R}_{5}$ ) of some commercial fruit juices are presented in tables 1 and 2 . The bacterial level at $10 \mathrm{ml}$ volume for samples R1-R5 were:0,1,0,1,1 and at $1 \mathrm{ml}$ volume, the levels were:1,2,0,1,1.The MPN $/ 100 \mathrm{ml}$ at $37{ }^{0} \mathrm{C}$ were: $1,3,0,2,2$, for $\mathrm{R}_{1}, \mathrm{R}_{2}, \mathrm{R}_{3}, \mathrm{R}_{4}$ and $\mathrm{R}_{5}$. (Table1).

Table 1: The most probable number of juice samples obtained within FUTO

\begin{tabular}{|l|l|l|l|}
\hline Samples & $10 \mathrm{ml}$ & $1 \mathrm{ml}$ & MPN/100 \\
\hline $\mathrm{R}_{1}$ & 0 & 1 & 1 \\
$\mathrm{R}_{2}$ & 1 & 2 & 3 \\
$\mathrm{R}_{3}$ & 0 & 0 & 0 \\
$\mathrm{R}_{4}$ & 1 & 1 & 2 \\
$\mathrm{R}_{5}$ & 1 & 1 & 2 \\
\hline
\end{tabular}

The percentage bacterial counts for the sampled organisms are shown in table 2. The results show a zero count for $S$. typhymurium while $E$. coli and $S$. aureus had $34.15 \%$. The results also show the absence of $S$. typhymurium in all the samples. The prevalence of $S$. aureus was relatively high in samples $\mathrm{R}_{4}$ and $\mathrm{R}_{1}$ while E. coli was highest in sample $R_{2}$. There was no growth of the tested organisms in sample $R_{3}$.

Table 2: Microbial screening of Juice samples obtained within FUTO

\begin{tabular}{|l|l|l|l|l|l|l|}
\hline Bacteria species & $\%$ Bacteria count & $\mathrm{R}_{1}$ & $\mathrm{R}_{2}$ & $\mathrm{R}_{3}$ & $\mathrm{R}_{4}$ & $\mathrm{R}_{5}$ \\
\hline Escherichia coli & 34.15 & 2 & 6 & 0 & 4 & 2 \\
Klebsiella pneumoniae & 14.63 & 2 & 1 & 0 & 2 & 1 \\
Staphylococcus aureus & 34.15 & 4 & 2 & 0 & 5 & 3 \\
Salmonella typhymurium & 0.00 & 0 & 0 & 0 & 0 & 0 \\
Streptococcus faecalis & 17.07 & 2 & 2 & 0 & 2 & 1 \\
\hline
\end{tabular}

\section{Discussion}

This study assessed the safety of some commonly consumed commercial fruit juices in FUTO using microbiological analysis as an index of investigation. The absence of all the bacteria species in sample $R_{3}$ and the absence of MPN/100 in the same sample show that the sample was not contaminated and therefore safe for consumption. Most probable number(MPN) gives an approximate number of coliform in a fruit juice based on the theory of probability. Bestshart(16) has reported the presence of E. coli, S. aureus, S. typhymurium and $S$. faecalis in contaminated food. The absence of $S$. typhymurium in all the samples analyzed is suggesting that the samples may not be a source of typhoid fever in the community. Salmonella specie is a common cause of typhoid fever (17,18).Food borne and water borne diseases are of public health significance(19). Some E. coli, $K$. pneumoniae ,S. aureus and $S$. faecalis were detected in the samples $\mathrm{R}_{1}, \mathrm{R}_{2}, \mathrm{R}_{4}$ and $\mathrm{R}_{5}$. However, this is suggesting that these samples $R_{1}, R_{2}, R_{4}$, and $R_{5}$ were not safe for consumption even though the colonies of bacteria detected were not significant to cause infection. Some of these associated microbes have been implicated in food poisoning outbreak of some food materials (20). The presence of E. coli in food is an 
indication of faecal contamination of product(21). Previous reports(4,21) showed that the presence of $E$.coli in hawked drinks is not unexpected since the source of water used in many parts of Eastern Nigeria is tap or borehole water. Coliforms has been reportedly associated with tap water popularly consumed in some towns in Nigeria(21).The presence of Staphylococcus species in samples $R_{1}, R_{2}, R_{4}$ and $R_{5}$ could be as a result of contaminations from handlers. Staphylococcus aureus, a mesophile has been implicated in food poisoning outbreak of some food materials (2,18). Kurowska et al.(5) reported that Staphylococcus aureus levels of $108 \mathrm{ml}$ are considered potentially hazardous to consumers. This is a source of concern in Nigeria because the teaming populace relies on these drinks as alternatives to the bottled canned drinks whose prices are becoming unaffordable.

\subsection{Conclusion.}

The entire locally produced juice samples screened in this work were contaminated; hence, they are not safe for consumption. This may be as a result of poor handling. Educating the sellers, distributors and producers could be of help in reducing or eradicating incidences of water transmitted infections. Fruit juice drinks and allied products should be properly processed to avoid microbial contamination.

Competing interest

Authors have declared that no competing interests exist.

\section{References}

[1] NA .Amusa, OA. Ashaye, MO .Aiyegbayo, MO.Oladapo, O. Afolabi, OO. Microbiological, Nutritional quality of hawked sorrel drinks(Soborodo, the Nigerian locally brewed soft drinks) widely consumed in Nigeria. Int. J. Fd. Agric. Env. 2005; 3(4):47-50.

[2] A A. Adebesin, OT.Saromi, N A. Amusa, S O. Fagade, Microbiological quality of some groundnut products hawked in Bauchi, a Nigerian city. J. Fd. Tech. 2001; 6:35-8

[3] A A , Franke AV .Cooney, SM .Henning, I J. Cluster, Bioavailability and antioxidant effects of orange juice components in humans. J. Agric. Fd. Chem. 2005; 53(13):5170-8.

[4] N A. Amusa O A. Asheye, Effect of processing on nutritional, microbiological and sensory properties of Kunu-Zaki (A sorghum based non-alcoholic beverage)widely consumed in Nigeria. Pak. J. Nutr. 2009;8(3):288-92.

[5] E M. Kurowska, J D.Spence, J. Jordan, S. Wetmore, D J. Freeman, L A. Piche, HDL-Cholesterol-raising effect of orange juice in subjects with hypercholesterolemia. Am. J. Clin. Nutr. 2000;72(5):1095-100.

[6] M L. Kwan, G. Block, A. Selvins, S.Month PA. Buffler, Food consumption by children and risk of childhood acute leukemia. Am. J. Epidemiol. 2004;160(11):1098-107.

[7] JM. Chan, F. Wang, E A. Holly, Vegetable and fruit intake and pancreatic cancer in a population based case-control study in the San Francisco bay area. Cancer Epidemiol. Biomarkers Prev. 2005;14(9):2093.

[8] O.Dai A R. Borenstain, JC. Jackson, EB. Larson, Fruit and vegetable juices and Alzheimer's disease, the Kame project. Am. J. Med. 2006;119(9): 751-9.

[9] E B. Feldman, Fruit and vegetables and risk of stroke. Nutr. Rev. 2001; 59(1):24-7.

[10] A. Gil-Izquerdo, MI. Gil, FA. Tomas-Barberman, F. Ferreres, Influence of industrial processing in orange juice flavanone solubility and transformation to chalcones under gastrointestinal conditions. J. Agric Fd Chem. 2003; 51:3024.

[11] JH. Hollis, JA. Houchins, J. Blumbery, RD. Mattes, Effects of concord grape on appetite diet, body weight,lipid profile, and antioxidant status of adults J. Am. Coll. Nutr. 2009; 28 (5):574-582.

[12] MF. Tosi, A A. Hamedani, A rapid specific assay for superoxide release from phagocytes in small volumes of whole blood. Am. J. Clin. Pathol. 1992; 97: 566.

[13] JE. Lewis, H. Soler-Vila, PE. Clark LA. Krestly, GO. Allen, JJ. Hu, Intake of plant foods and associated nutrients in prostate cancer risk. Nutr. Cancer. 2009; 61 (2): 216-24.

[14] E. Essien, C. Monago, A. Edor, Evaluation of the nutritional and microbiological quality of kunun. Int. J. Nutr. wellness. 2011;10 (2):2.DOI:10.558018e 7

[15] Chessbrough M. Laboratory manual for tropical countries ( $3^{\text {rd }}$ ed.). Tropical Health Techniques London. 2001

[16]. Bestshart A A. World food and nutrition problems. Cereal Fd World. 1982; 27:562.

[17] H. Ghanim, CL. Sai, M. Upadhyay, K. Korzeniewski P. Viswanathan, Abuaysehe S, et al., Orange juice neutralizes the proinflammatory effect of a high- fat diet. Am. J.Clin. Nutr. 2011;93 (3):674.

[18] Odunfa S A. A. Adeyeye, Microbiological changes during the traditional production of Ogibaba, a West African fermented sorghum. J Cereal Sci. 1988; 3: 173-180.

[19] J. Kluytmans, B A. Van H. Verbrugh, Nasal carriage of Staphylococcus aureus, epidemiology underlying mechanisms and associated risk. Clin. Microbiol. 1997; 10(3): 505-20.

[20] D P. Sartory I. Howard, A medium detecting galuconidase from the simulataneous membrane filtration enumeration of Escherichia coli and coliforms from drinking water. Lett. Appl. Microbiol. 1992; 15: 147-148.

[21] S T. Onuorah, A A, Adesivu J O. Adekeye, Occurrence of Staphylococci and Coliform in Kunun, Zaki and food utensils used in its preparation in Samaru, Zaria. J. Food Agric. 1987; 1:31-34. 